Article

\title{
Corporate Social Responsibility in Global Supply Chains: Deeds Not Words
}

\author{
Holger Görg ${ }^{1, *}$, Aoife Hanley ${ }^{1}$ and Adnan Seric ${ }^{1,2}$ \\ 1 Kiel Centre for Globalization, Kiel Institute for the World Economy, Kiellinie 66, 24105 Kiel, Germany; \\ aoife.hanley@ifw-kiel.de (A.H.); a.seric@unido.org (A.S.) \\ 2 United Nations Industrial Development Organization, 1400 Vienna, Austria \\ * Correspondence: holger.goerg@ifw-kiel.de
}

Received: 4 September 2018; Accepted: 9 October 2018; Published: 14 October 2018

check for updates

\begin{abstract}
The disconnect between the lofty aspirations of firms claiming Corporate Social Responsibility (CSR) and their shortcomings in practice have caused some observers to question its usefulness. The fallout from events like the Rana Plaza catastrophe has highlighted some of these shortcomings-namely, deficiencies in how multinational enterprises (MNEs) transact with suppliers in developing countries. Specifically, our paper aims to investigate whether or not MNEs behave hypocritically by examining the alignment of CSR to business practices in MNE affiliates in developing countries. To answer this question, we apply standard ordinary least squares (OLS) techniques to data for over 1000 MNEs that claim to have a CSR ethos. We find that CSR-active enterprises report significantly higher worker wages, ceteris paribus. Local African suppliers benefit from CSR through knowledge transfer, but only when MNEs make tangible investments in supplier development.
\end{abstract}

Keywords: corporate social responsibility; corporate hypocrisy; Africa; wages; knowledge transfer

JEL Classification: F23; M14; O14

\section{Introduction}

In recent years, increasingly complex global supply chains have arisen, where multinational enterprises (MNEs) organize their production using suppliers around the globe. A well-studied example is the Apple iPhone, where inputs from a number of countries, including Germany, South Korea, Japan, and the United States (US) are assembled in China, and the semi-finished product is then shipped to the US for final marketing and sales [1].

Critics have claimed that the organization of production activities, especially if involving production in low-income countries, has not been done in a socially responsible way. Global supply chains, the argument goes, have led to the exploitation of foreign workers and the environment. For example, a 2014 Oxfam report [2] raises the issue of decent working conditions and the role of "responsible companies" in global supply chains. In a similar vein, the British Prime Minister, Theresa May, during her 2017 speech in Davos, insisted that businesses would have to recognize their obligations and duties to employees and supply chains, and they act in socially responsible ways with respect to the communities and nations where they operate (Source: Companies must share benefits of globalization, Theresa May tells Davos, The Guardian, 19 January 2017).

Many businesses use Corporate Social Responsibility (CSR) activities to signal to stakeholders that they are concerned about these issues, and willing to take action. Yet, many have lost faith in CSR as a way of distinguishing between genuinely conscientious firms and firms that are only masquerading as such [3-5]. The differences between firms observed behaviour and their stated CSR standards are taken as indicators of "corporate hypocrisy". One example of this is "greenwashing", whereby firms 
provide misleading information about environmental aspects of their products or production process to consumers $[6,7]$.

In order to investigate whether or not MNEs behave hypocritically, we examine the alignment of CSR to business practices in the affiliates of MNEs in developing countries. Specifically, we use information about the CSR orientation of MNEs to separate what we refer to as "verbal CSR"

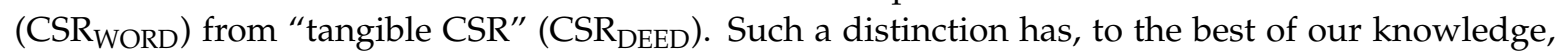
not been made in the literature to date and it is one of the novelties of our paper.

We investigate whether the behaviour of MNEs that are engaged in CSR activities (either CSR ${ }_{W O R D}$

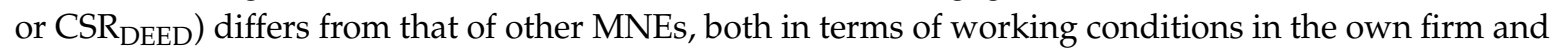
their interaction with suppliers. Our analysis is divided into two parts. In the first part, we investigate how wages in affiliates of MNEs that are engaged in CSR differ from those in comparable affiliates not conducting CSR. In the second part, we shift our focus to the relationship between the multinational and its local suppliers, searching for evidence of knowledge transfer between the former and the latter. The empirical analysis uses firm level data from 19 Sub-Saharan African countries.

Our paper also contributes to the literature in other ways. While most of the burgeoning literature on CSR activities of firms, as summarised in [8-10] looks at the drivers of CSR [11,12] and the implications for the value of the firm $[13,14]$, we look at the link between CSR and outcomes in the firm from a different angle: The connection between labour conditions and CSR implementation. While existing research shows that CSR can impact on employee engagement and retention [8], we look specifically at wages. This has, to the best of our knowledge, not been done in the literature.

Furthermore, we place CSR practices firmly within the global supply chain, investigating whether MNEs conducting CSR enjoy enhanced relationships with their local supplier as compared to MNEs without CSR. The relationship between 'responsible' MNEs and their local suppliers has, to our knowledge, only received scant attention in the global supply chain literature (see [9] for a succinct overview). Thirdly, while, up to now, the spotlight in terms of CSR in global supply chains has tended to focus on Asia (e.g., garments procurement), other developing parts of the world, most notably the African continent, have remained under researched. We fill this gap, using firm level data for 19 Sub-Saharan African countries for our study.

Our paper is structured, as follows. The next section discusses the relevant background literature and motivates our hypotheses. Section 3 describes the dataset used in our paper. Section 4 examines the relationship between verbal and tangible CSR investments and wages, as well as help provided to developing-country suppliers. Section 5 concludes.

\section{Background}

There is no clear-cut definition in the literature of what is meant by CSR. McWilliams and Siegel [15] define it as "actions that appear to further some social good, beyond the interests of the firm and that which is required by law", while Matten and Moon [16] consider CSR as firms' implicit compliance with business norms set by societies. Crouch [17] sees CSR activities as attempts to reduce the negative externalities imposed on societies. Others argue that CSR encompasses those activities into which firms invest in order to conform to ethical standards (set, e.g., by Non-Governmental Organisations, the media, consumers, or other stakeholders) in their production (e.g., [18-20]). Not doing so may have adverse consequences for a firm's reputation and ultimately success on the market place.

While the literature on CSR has been around for a relatively long time, studies on international CSR are comparatively scarce. As such, relatively little empirical work is available documenting the role of CSR in global value chains. As [10] (p. 76) conclude in their excellent review of the literature: "Both the theory and empirics of CSR in an international context are underdeveloped. Transitional economies typically have limited formal regulation, so CSR may be especially important". Where such studies do exist, they tend to be frequently based on case studies as in [21] or [22]. 
Before we begin our presentation of the relevant empirical work, it is worth taking a look at the mechanism by which large corporations are expected to behave responsibly towards foreign suppliers in a value chain. Baron maps out these relationships in a model of morally motivated self-regulation [23]. His model considers a prisoner's dilemma where participants experience feelings of guilt if they do not cooperate. Importantly for CSR in an international context, Baron's model describes what factors prompt managers to act responsibly. If agents (e.g., managers in multinational firms and end-customers) are motivated by limited morality, they will only behave responsibly towards foreign workers with whom they closely identify. Baron also considers a second moral regimen, reciprocal altruism, where decision makers behave altruistically in the expectation that workers will reciprocate by working more productively. However, there is no guarantee that foreign workers will indeed reciprocate. Accordingly, raising work standards is not a cost neutral strategy for ethical managers. At the same time, there is an incentive for competing firms to undercut the sales of socially responsible firms. Baron concludes that certification (e.g., the Fair Trade label) can help to raise welfare for workers in foreign firms under a reciprocal altruism regime. However, under limited morality, end consumers might not care enough about foreign worker welfare to pay a premium price for ethically produced products. Baron concludes that ideally, firms will self-regulate, collectively and on their own initiative.

Now, we shift the focus to how international CSR works in practice. Many international firms claiming to be socially responsible, draw up CSR codes of practice [3]. These codes are largely based on those that were published by international bodies (e.g., UN Universal Declaration of Human Rights). However, UNCTAD notes that the CSR codes adopted and advertised by firms frequently only reflect the minimum international legal standard [3]. Additionally, these CSR codes of practice suffer a further shortcoming, as pointed out by UNCTAD [3]: Due to the complexity of global value chains and their lack of transparency, some multinational corporations tend to shift responsibility for labour standards back to their first tier suppliers.

Furthermore, CSR in global chains gets weakened in another important way-the distance between the practices of firms and the end customer. One major intuition for adopting CSR is to avoid bad publicity [21]. But firms operating in sectors that are less visible to end customers may see no need to safeguard their reputations by implementing CSR. Fortunately, larger multinationals with established reputations are more likely to comply with CSR standards, as revealed by [22]. Furthermore, Boehe et al. and Görg et al. [24,25] provide evidence that multinationals that export to developed countries (where consumers are likely to be concerned about social issues) are more likely to be involved in CSR activities.

Still, the contentious question remains: do multinationals that claim to apply CSR actually deliver on this promise? [26] (p. 3) argues that "... the growth of 'global value chains', through which Northern buyers control a web of suppliers in the South, has led to calls for them to take responsibility not only for aspects such as quality and delivery dates, but also for working conditions and environmental impacts". However, in their extensive discussion of the literature, Lund-Thomsen and Lindgreen conclude that ".we find limited evidence that international buyers systematically cut ties with factories in response to their low social or environmental compliance levels" [9].

When a firm's activities fail to match its CSR standards-either the standards that the firm advertised to outsiders or internal stakeholders [5] - the firm is judged have behaved hypocritically [27]. When this happens, we can conclude that the firm's business practices have become 'decoupled' from its CSR standards [28].

Hypocritical CSR has already been examined in the literature (e.g., [4]). However, previous analyses tend to be restricted to single-country consumers or corporations. More recently, researchers, like Lock and Seele [29], have called for future work that widens the research lens to include all domestic and, additionally, foreign customers and suppliers with whom an MNE transacts. Only then, can we obtain a global blueprint of CSR. 
MNEs not only operate across international borders but also across industries. For this reason, researchers have been raising the profile of 'contextual factors' (e.g., industry and firm size) as potential factors that improve/undermine the credibility of CSR. MNEs that are positioned in highly regulated industries are unwilling to attract further scrutiny. Accordingly, such firms are least likely to act hypocritically [30]. Furthermore, Lock and Seele [29], examining the credibility of 237 CSR reports, consider the role of contextual factors (e.g., firm size and industry) in helping to explain the credibility of these reports. Using a combination of human and software-enhanced quantitative content analysis, the latter found that report clarity (not contextual factors) mattered most for credibility. Nevertheless, the Lock and Seele [29] study is unique in considering the role of context.

The study by Stender et al. [31], examining the variation in nutritional values across countries by the fast food chain McDonalds, similarly emphasizes the importance of looking at country context when evaluating the honesty of corporations. Yet, the role of country (importing developed-country MNE and exporting developing-country supplier) appears to be under-researched in the literature. This gap in our understanding of how MNEs behave in developing countries, is corroborated by Kitzmueller and Shimshack [10], who argue that "both the theory and empirics of CSR in an international context are underdeveloped." (p. 76)

Despite the absence of empirical studies in this area, the debate has been taken up in the popular media and by online communities (e.g., China Labor Watch, an online NGO) where a growing number of revelations about shoddy work practices among producers has turned the spotlight on the relationships between MNEs and their overseas producers. Perhaps this flurry of media attention, has made firms shy about their CSR credentials [31] as we proceed to demonstrate.

Multinational firms enjoy (or suffer) enormous media attention. As such, customers and private individuals are often made aware of instances where large corporations, like Starbucks, IKEA, and Gap are seen to have transgressed against the normal rules of decency. The reputation loss for these firms is severe $[27,32,33]$. For this reason, some multinational firms may have become increasingly cautious about telling the world how they treat their developing country suppliers for fear of being exposed as hypocritical. Multinationals do not merely fear censure from customers and private individuals. Rather tellingly, it is inside-stakeholders i.e., shareholders, whose criticisms seem to matter most [34].

Kim and Lyon [34] analyse the decision that was taken by US firms to communicate their adoption of a voluntary environmental standard. What is interesting about this study is that it reveals the conflicting interests of the firm's stakeholders: shareholders being primarily concerned with profits-customers with environmental responsibility. Due to the perception that corporate responsibility erodes profits, managers generally prefer not to advertise the firm's environmental successes in years when the firm is underperforming. Managers adopt this 'brownwashing' tactic - undue modesty about environmental successes-to avoid attracting negative scrutiny from shareholders. Alternatively, in years of buoyant growth, managers feel less worried about reporting their CSR activities. Similarly, Carlos and Lewis [27], in their analysis of firms that are listed on the Dow Jones Sustainability Index, explore the concept of 'hypocrisy avoidance' where firms deliberately downplay their environmental achievements to avoid inviting public scrutiny into these achievements. The reputation loss of any inconsistencies in the firm's message would far outweigh the gains to be made, were the firm to be vindicated because its CSR message was seen to be consistent.

We now delve deeper into the idea of corporate hypocrisy: can this abstract concept be operationalized? In the simplest sense, hypocrisy arises when deeds fail to match up with words. The "deeds" can be numerous, and there are two aspects that we focus on here. The first aspect is working conditions within a firm. If CSR is considered to be important, we would expect a firm to provide decent working conditions. Another aspect is assistance to suppliers. A CSR active firm may be concerned about working conditions within supplier firms, and therefore provide assistance to the supplier that enables it to improve its production technology, helping it to achieve better labour standards. 
The above discussion centres on the dimensions of CSR. From this, we can form ideas for operationalizing CSR when examining data for MNEs. We can broadly distinguish between two forms of CSR: verbal (CSR WORD) and tangible (CSR $\left.{ }_{\text {DEED }}\right)$. Consider the possibility for MNEs to undertake two separate CSR strategies: The first is a verbal strategy, CSR $_{\text {WORD }}$. CSR WORD $_{\text {allowing a firm to }}$ advertise to consumers the firm's intentions to pay fair wages or employ minority groups in developing countries. Due to information asymmetries, this verbal strategy will attract both honest as well as dishonest firms. Consumers will be unable to discriminate between both types of firm. Of course, stakeholders can be alerted to the hypocritical actions of dishonest firms through the actions of NGOs or undercover journalists [21]. But, not all firms are large, high-profile, and therefore subject to the same level of scrutiny. Many firms, including firms that trade in intermediate products, can still avoid scrutiny and find that hypocrisy can pay. Therefore, MNEs that are engaged in the verbal strategy may not be different in terms of outcome as compared to MNEs that do not engage in CSR at all.

The second CSR strategy, CSR $_{\mathrm{DEED}}$, implies that firms actively invest in assisting their local developing-country suppliers. A first tangible step towards such investments is the establishment of a department for fostering local supplier development within the MNE. This is a costly investment for any firm. Given that the investment is costly and that actions are harder to falsify than words, we expect only honest firms to take this step. We would expect these MNEs to be different than other MNEs that do not invest in CSR.

Based on these arguments we would expect that, on average, the welfare outcomes (better working conditions or assistance to suppliers) for verbal CSR, CSR WORD, are lower than for non-verbal CSR, $\mathrm{CSR}_{\mathrm{DEED}}$. This is summarized in the following hypothesis:

Hypothesis 1: MNEs engaged only in verbal CSR may not be different from MNEs not engaged in CSR at all. Welfare outcomes for workers and suppliers in developing countries are expected to be higher from non-verbal, tangible CSR. These welfare outcomes relate to working conditions in the firm, and technical assistance provided to local suppliers.

So far we have looked directly at the message sent out by firms, seeking for reasons to explain why firms under- or over-report their CSR credentials. Our emphasis has been on the 'CSR message'. We now look at an alternative motive for positive welfare outcomes (in terms of working conditions and supplier assistance) that have nothing to do with the self-professed importance of CSR to the firm.

It is somewhat of a stylized fact that the demands of company shareholders have priority over the demands of other stakeholders [27]. The profit-making objective dominates over any other. What have other studies revealed about the relationship between profit-making MNEs and their suppliers in developing countries?

Some academics have called for firms in global value chains to help their foreign suppliers to upgrade their manufacturing capability and assist with worker training and technology upgrading $[9,22]$. There is a growing consensus that MNEs should invest in the production and skill upgrading of their foreign suppliers. But, knowledge transfer is costly [23] and relatively rare. Birkinshaw et al. [35] (p. 23) neatly summarize this superficial approach towards genuinely improving working conditions through knowledge transfer:

"For senior executives, knowledge transfer, knowledge-sharing, and social communities are interesting nice-to-haves, but they are rarely strategic imperatives (our highlighting). Senior executives are far more worried about such issues as corporate social responsibility and so on."

Still, multinational firms operating in a developing country may decide to adopt a different approach towards knowledge sharing, if a failure to work together with developing-country suppliers is detrimental to product quality. It is not unreasonable to argue that knowledge sharing with developing-country suppliers, under certain circumstances, does become a strategic imperative. We illustrate this point by referring to the Mattel scandal, where toys that were sourced from China 
had to be recalled due to lead paint being used in the production process [4]. Knowledge sharing must take place when the sensitivities of customers in high-end export markets are paramount.

Consider an MNE operating in an agrarian region in Africa, producing super-foods for end-customers in Hamburg or Delhi, respectively. Wealthy, educated customers from Hamburg are more able — and arguably more willing - to pay a price premium for an ethically produced product $[24,25]$. Poorer customers from Delhi, being more price conscious, are less likely to accept a price premium for the same ethically produced product. Accordingly, a major determinant of production choice - and hence determinant of working conditions-is the end-user.

Developing-country suppliers can become net beneficiaries in the process, if multinationals prioritize the demands of high-end customers in export markets for high-quality, ethically sourced products. A multinational whose overriding goal is to make profits may, under these circumstances, choose to assist its developing-country suppliers to enable them to improve production processes, provide better working conditions, and ultimately provide better quality intermediates.

On the basis of these arguments, we can formulate the following testable hypothesis:

Hypothesis 2: Although MNEs do not willingly share knowledge with developing-country suppliers, when the sensitivities of high-end customers in export markets for ethically sourced and high-quality goods are considered, knowledge-sharing takes place.

\section{Data and Descriptives}

To investigate our hypotheses empirically, we use unique firm-level data collected through the UNIDO Africa Investor Survey 2010 across 19 Sub-Saharan Africa countries (Burkina Faso, Burundi, Cameroon, Cape Verde, Ethiopia, Ghana, Kenya, Lesotho, Madagascar, Malawi, Mali, Mozambique, Niger, Nigeria, Rwanda, Senegal, Tanzania, Uganda, and Zambia). The Foreign Investor Survey data contains a rich set of information on a large sample of foreign owned firms, i.e., affiliates of foreign MNEs located in these countries. The collection of the dataset followed a rigorous survey methodology that involved stratified sampling (on three dimensions: sector, size, and ownership) in order to construct a sample of firms that is representative of public and private firms with 10 or more employees, within the countries. An oversampling of relatively large firms ( $>100$ employees) was implemented. The firms were then interviewed by highly-trained enumerators using face-to-face interviews with top-level managers of foreign MNEs. Overall, 2113 foreign-owned MNEs participated in the survey. More details on the Africa Investor Survey 2010, the sampling procedure and quality assurance measures are provided in UNIDO [36].

There is no established way to measure CSR in the literature. In our survey data, we have two items of information that we use to measure CSR activities by MNEs. The first one is based on the MNE's self-reported reasons for choosing local suppliers. We define a dummy variable CSR-Word equal to 1 if a firm cites as its main reason for local supplier choice "corporate commitment to local supplier development in the region". Specifically, this encompasses social concerns about suppliers, including working conditions, wages, and sustainable development of the supplier. A similar measure is also used by Görg et al. [15] to capture a firm's approach to CSR. In sum, the dummy variable CSR-Word denotes a stated commitment from the MNE to care for the African supplier.

Other possible options for answering are "raw materials", "logistics", "closer supplier relationship", "reduced tariff", "local content", "fiscal or tax efficiency", "improved acceptability", "environmental responsibility", or "others". The survey design forced the respondents to tick only one box representing the most important reason for the sourcing decision. We acknowledge that this is a very stringent definition of CSR considerations in sourcing local content, by foreign MNEs. It captures MNEs that arguably place a very high emphasis on CSR in their corporate culture. It is of course possible that firms that do not report social concerns as the most salient reason for supplier choice, may still be concerned about CSR. Hence, our analysis is rather stringent and it only captures the strongest CSR implementers. 
Our second measure is based on a MNE's response to the question as to whether it has a dedicated department for local supplier development. If the answer to this question is yes, then we define a dummy variable CSR-Deed equal to 1 ( 0 otherwise). Our assumption is that the establishment of such a dedicated department is more than just a verbal profession of care towards the African supplier. CSR-Deed signals that the MNE has demonstrably invested in the local supplier development.

Such a distinction between CSR-Word and CSR-Deed has, to the best of our knowledge, not been performed in the literature to date. Table 1 shows that CSR, either in the choice of supplier or in the setting up of a local supplier development department, is relatively rare among the MNEs with affiliates in these 19 African countries. In our sample, around 2 percent of firms cite CSR considerations as the most important reason for the choice of supplier. While not all firms answer the question that is related to the local supplier development department, of those that do, only 10 percent answer in the affirmative.

Table 1. Use of Corporate Social Responsibility (CSR) activities.

\begin{tabular}{ccc}
\hline Measure of CSR & Number of Firms & \% of Total \\
\hline MNE claims to care about supplier (CSR-Word) & 50 & 2.1 \\
MNE invests in supplier (CSR-Deed) & 131 & 9.6 \\
\hline
\end{tabular}

This indicates that CSR considerations appear to play only a minor role among MNEs in our sample.

Recall that the purpose of our paper is to investigate the relationship between measures of CSR applied by MNEs operating in Africa and welfare outcomes that are associated with these measures. In terms of welfare outcomes, there are two issues that we look at: wages (as a proxy for working conditions) in the firm itself, and knowledge transfer to the local suppliers in the African host country. Wages are measured as the average monthly wage paid in a firm. Knowledge transfer takes place if affiliates respond in the survey that they help local suppliers with "upgrading the quality of their workforce", "access to finance", or "transfer of technology" (i.e., technology related to production efficiency, product quality, and design).

To begin the analysis, we first browse the data with a view to discerning patterns between the key variables related to our hypotheses, before turning to a more formal econometric analysis in the next section. We consider the nature of the firm's social responsibility (CSR-Deed or Word) as defined above, and expect those firms active in CSR to show higher welfare outcomes (Hypothesis 1). We also consider the firm's export orientation, whether or not the firm in Africa exports to the "North" (defined as European Union, United States, and other developed countries). Our intuition is that firms exporting a high share of their output to consumers in developed countries are more likely to be held responsible for their behaviour towards developing country stakeholders (Hypothesis 2).

The first two diagrams (Figures 1 and 2) describe the average wages of African workers, with/without the implementation of CSR (Word or Deed) and with/without an export orientation towards developed countries. Interestingly, we do not find clear support for either Hypothesis 1 or Hypothesis 2. Instead of witnessing a shift towards higher category wages with more active CSR or an export orientation towards developed countries, the pattern is unclear. This suggests that other factors are at play, apart from the drivers (export orientation and CSR) that we have identified.

The latter two diagrams (Figures 3 and 4) illustrate the outcome for knowledge transfer. Here the pattern is clear and Hypothesis 1 and Hypothesis 2 are supported. MNEs that export an above-average share of their exports to the developed North and which implement CSR (Word and Deed) are more likely to transfer knowledge to their African partners. Additionally, the role of active CSR (CSR-Deed) in promoting positive CSR outcomes appears to be stronger than CSR-Word. Specifically, we see that firms applying active CSR are more likely to transfer knowledge to their African partner firms. 


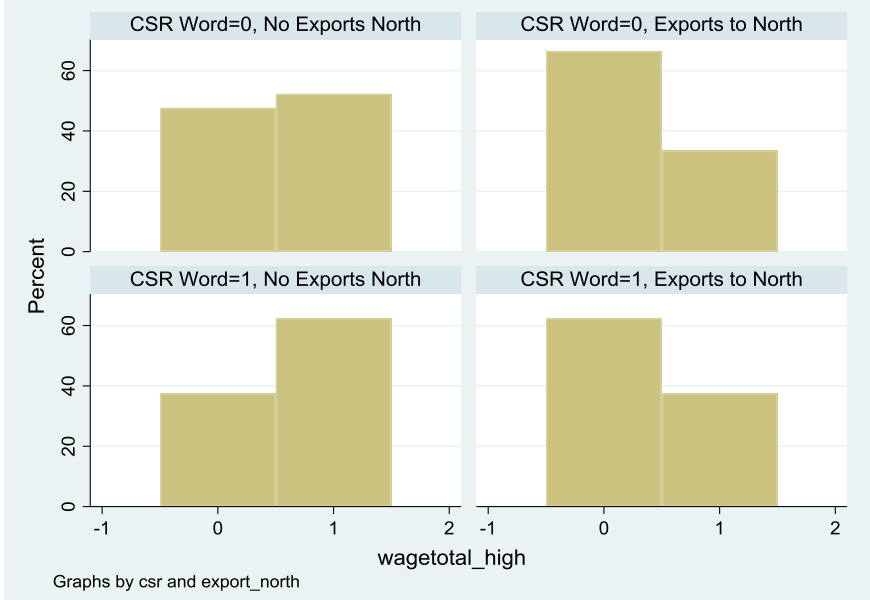

Figure 1. CSR-Word, Wages, and Export Orientation.

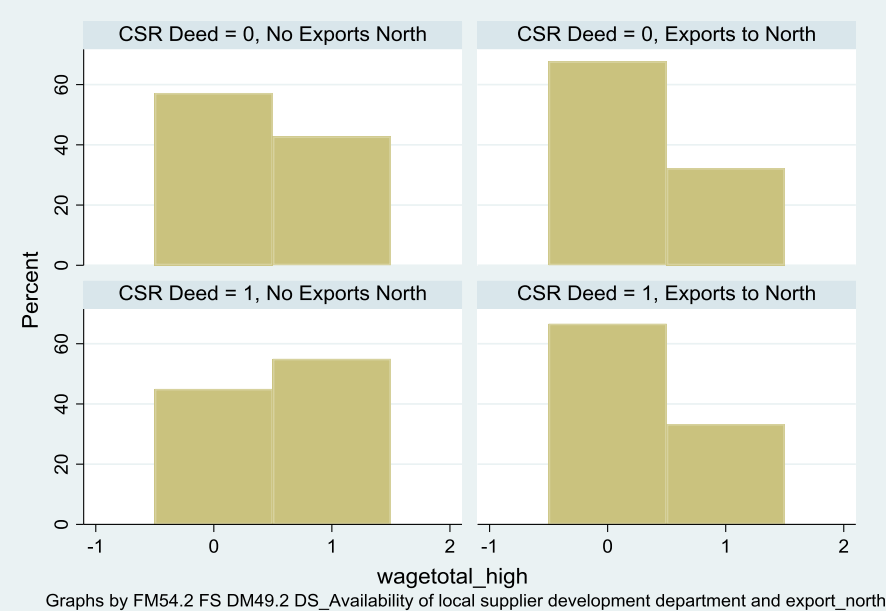

Figure 2. CSR-Deed, Wages, and Export Orientation.

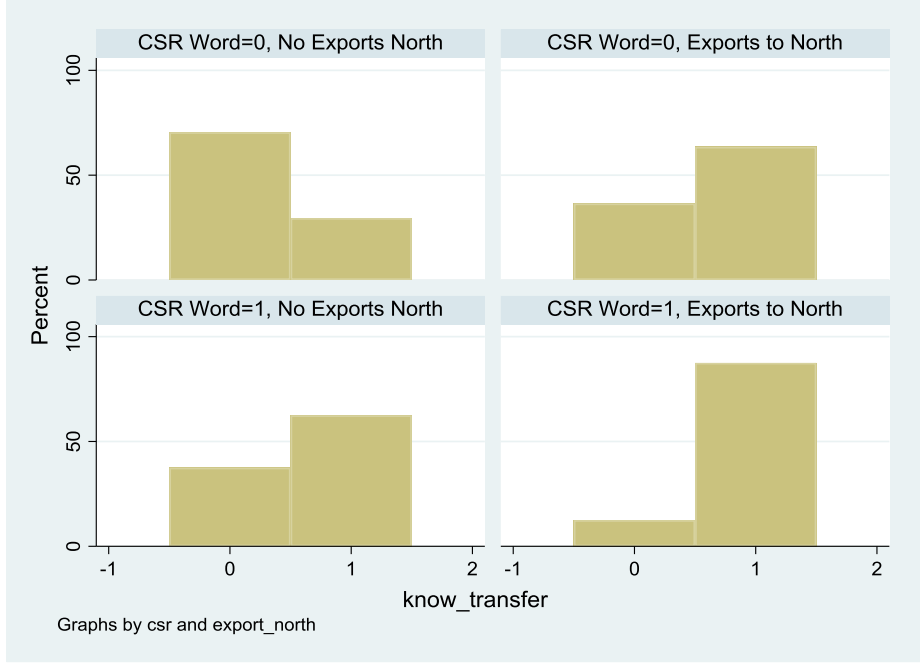

Figure 3. CSR-Word, Knowledge Transfer, and Export Orientation. 


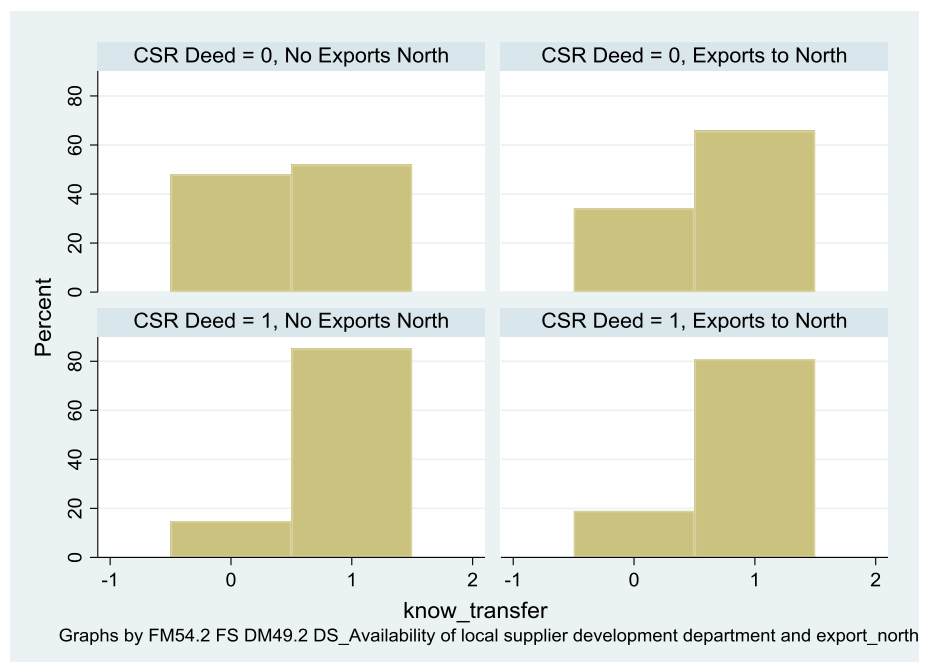

Figure 4. CSR-Deed, Knowledge Transfer, and Export Orientation.

While these relationships are indicative of the hypothesised roles of CSR and exporting for knowledge transfer if not for wages-we now turn to a more formal econometric analysis to consider other potential sources of heterogeneity in CSR outcomes (e.g., firm size and sector).

\section{Econometric Analysis}

In the next step of the analysis, we start off by looking at internal working conditions in the multinational enterprise, i.e., the MNE's affiliate. If MNEs are not hypocritical in their actions, then we might expect that those claiming to care about CSR do indeed behave responsibly towards their own workers. This should also be true for MNEs selling goods to developed countries (the North). Accordingly, we should witness higher wages for employees in CSR-active firms or in firms exporting to the North, as compared to firms that do not do either. To investigate this, we estimate simple empirical models of the form,

$$
\ln (\text { wage })_{i}=\alpha_{1} \text { CSR }_{i}+\alpha_{2} \text { export_north }{ }_{i}+\alpha_{3} \text { controls }_{i}+d_{c}+d_{s}+\varepsilon
$$

where we use the average monthly wage paid in a firm as the dependent variable. Additionally, we are able to distinguish the monthly wage in a firm paid to production workers and technical/managerial workers. We can broadly consider the former to be unskilled workers, while technical and managerial employees are more high-skilled.

CSR is a vector containing the dummy variables CSR-Word and CSR-Deed for firm i. Export-north is a dummy equal to one if the firm reports exports to developed countries (EU, North America, other developed countries). The vector controls includes firm-level controls, namely, log firm age (defined based on the reported year of starting operations in the country), log firm employment size (based on reported number of full time employees), and a dummy whether a firm reports advertising expenditure higher than the median value in the sample. Furthermore, $d_{c}$ and $d_{s}$ are sets of dummy variables for host country $c$ and sector $s$ and $\varepsilon_{\mathrm{i}}$ is a white noise error term. A description of the sectors used can be found in Appendix A.

The firm, sector, and host country control variables are included in order to control for heterogeneity along these dimensions and allow us to better identify the effect of CSR and exporting, rather than of correlated firm, sector, or country characteristics. Regarding firm age, firm size, and advertising expenditure, several studies have shown that larger firms and those with higher advertising are more likely to use CSR $[24,25,37,38]$. At the same time, larger and older firms are more likely to pay higher wages and to provide increased technology transfer [39,40]. 
The model is estimated using conventional ordinary least squares (OLS) techniques. This estimation technique has also been used by, e.g., [41] using the same dataset. With this estimation method, the estimated coefficients can only be interpreted as estimates of a causal effect in the absence of any correlation between the right-hand-side variables and the error term. In line with related work [41], we do not maintain this assumption and we do not interpret the coefficients as causal effects but as merely reflecting correlations between the right-hand-side variables and the dependent variable.

We start in Table 2 with the analysis of wage differences across CSR and non-CSR active affiliates. The goodness of fit, as indicated by the R-squared, is around 25 to 30 percent, which is not unusual for analyses using this type of cross-section data $[25,41]$. We find that MNEs that engage in CSR, also pay higher wages on average (column 1) than MNEs that are not engaged in CSR. These higher wages are only statistically significant, however, for firms that actively invest in supplier development (CSR-Deed). While the link between CSR and wages in the CSR active firm has, to the best of our knowledge, not been investigated in the literature, it resembles findings that multinationals generally pay higher wages than domestic firms [42]. We do not compare multinationals with domestic firms, however, but look at differences across MNEs.

From columns (2) and (3), we see that the latter pay higher wages both to their production and technical staff, suggesting that there is no bias towards skilled or unskilled workers. The point estimates indicate that the wage premium for production and technical workers is about 31 and 33 percent, respectively (as the coefficient is on a dummy variable in a log-linear model, the marginal effect is calculated as $\exp (\beta)-1)$. CSR-Word firms also pay higher wages to their skilled technical workers, but not to their production workers.

Exporting to the North is associated with lower wages on average, as shown in column (1). This is due to their paying lower wages to production workers, but not technical workers. This finding does not suggest, contrary to what is conjectured in our Hypothesis 2, that exporters are concerned about social outcomes because of pressures from their customers. Rather, it might indicate that exporters avail of low labour costs when producing in African countries.

Table 2. CSR and Wages.

\begin{tabular}{cccc}
\hline & \multicolumn{2}{c}{ y Variable: Employee Wages by Job Category } \\
\cline { 2 - 4 } & $\mathbf{( 1 )}$ & $\mathbf{( 2 )}$ & $\mathbf{~ ( 3 ) ~}$ \\
\cline { 2 - 4 } & Total Wage & Production Workers & Technical Workers \\
\hline MNE claims to care about supplier (CSR-Word) & 0.165 & -0.026 & $0.288^{* *}$ \\
& $(0.101)$ & $(0.087)$ & $(0.128)$ \\
MNE invests in supplier (CSR-Deed) & $0.238^{* * *}$ & $0.270^{* * *}$ & $0.287^{* * *}$ \\
& $(0.093)$ & $(0.102)$ & $(0.103)$ \\
Export to North & $-0.135^{* *}$ & $-0.094^{*}$ & 0.106 \\
& $(0.057)$ & $(0.057)$ & $(0.073)$ \\
Observations & 1058 & 1083 & 1073 \\
Adj. R-squared & 0.30 & 0.29 & 0.26 \\
\hline
\end{tabular}

Notes: regression includes all firm level controls as well as host country and sector dummies as outlined in Equation (1). Robust standard errors are in parentheses. ${ }^{* * * * * *}$ and ${ }^{*}$ denote statistical significance at the 1,5 and 10 percent level, respectively.

In extensions to the analysis reported in Table 2, we also investigated various interaction terms. Firstly, we considered whether firms performing both CSR-Word and CSR-Deed behave differently than firms that only perform one of the two. As only very few firms-in fact only nine-do both, this did not return any statistically significant and meaningful results. We also interacted the CSR and exporting variables in order to see whether CSR matters more or less if firms export to the North. Again, however, this did not return any statistically significant coefficients on the interaction terms.

We now turn to the relationship between the foreign MNEs and their local suppliers, and investigate whether CSR-active MNEs or those that export to the North differ from other firms in terms of knowledge transfer to local suppliers. 
We use the firm level data to estimate equations of the form

$$
\text { knowledge_transfer } r_{i}=\beta_{1} \text { CSR }_{i}+\beta_{2} \text { export_north }{ }_{i}+\beta_{2} \text { controls }_{i}+d_{c}+d_{s}+v_{i}
$$

Here, we examine how affiliates provide knowledge transfer to their developing country supplier. Our data allow for us to distinguish three broad aspects of such knowledge transfer. The first type of knowledge transfer is whether affiliates help local suppliers with "upgrading the quality of their workforce". The second aspect is about knowledge related to "access to finance", and the third deals with "transfer of technology" (i.e., technology to do with production efficiency, product quality, and design).

Our dependent variable is firstly defined as a dummy equal to one if the firm reports any such knowledge transfer. We then consider the three aspects separately, defining dummies equal to one if the firm engages in the particular type of knowledge transfer. The right-hand-side variables are defined, as in Equation (1). Since the model has a binary dependent variable, it is estimated using a Probit estimator. This estimator has been used in analyses using this dataset $[25,39]$. Again, we do not maintain the assumption of exogeneity of regressors and therefore only interpret the coefficients as correlations rather than causal effects. We report marginal effects from this estimation in Table 3.

Table 3. CSR and knowledge transfer.

\begin{tabular}{|c|c|c|c|c|}
\hline & \multicolumn{4}{|c|}{ y Variable: Knowledge Transfer to Supplier } \\
\hline & (1) & (2) & (3) & (4) \\
\hline & Any transfer & Workforce Upgrading & Access to Finance & Technology, Design \& Efficiency \\
\hline MNE claims to care about supplier (CSR-Word) & $\begin{array}{c}0.131 \\
(0.079)\end{array}$ & $\begin{array}{c}0.108 \\
(0.079)\end{array}$ & $\begin{array}{c}0.030 \\
(0.064)\end{array}$ & $\begin{array}{c}0.099 \\
(0.084)\end{array}$ \\
\hline MNE invests in supplier (CSR-Deed) & $\begin{array}{c}0.274 * * * \\
(0.046)\end{array}$ & $\begin{array}{c}0.163 * * * \\
(0.052)\end{array}$ & $\begin{array}{c}0.119^{* *} \\
(0.048)\end{array}$ & $\begin{array}{c}0.281 * * * \\
(0.047)\end{array}$ \\
\hline Export to North & $\begin{array}{c}0.178^{* * *} \\
(0.043)\end{array}$ & $\begin{array}{c}0.105^{* * *} \\
(0.043)\end{array}$ & $\begin{array}{c}0.081 * * \\
(0.039)\end{array}$ & $\begin{array}{c}0.196^{* * *} \\
(0.043)\end{array}$ \\
\hline Observations & 1112 & 1097 & 1078 & 1112 \\
\hline Pseudo. R-squared & 0.10 & 0.11 & 0.08 & 0.10 \\
\hline
\end{tabular}

Notes: regression includes all firm level controls as well as host country and sector dummies as outlined in Equation (2). Robust standard errors are in parentheses. ${ }^{* * *}$ and ${ }^{* *}$ denote statistical significance at the 1 and 5 percent level, respectively.

In Column 1 of Table 3, we consider any type of knowledge transfer (dependent variable is equal to 1 for any knowledge transfer). The results show that CSR-Deed is positively associated with a transfer taking place. The point estimate suggests that CSR-Deed firms are about 27 percent more likely to engage in knowledge transfer than other firms. By contrast, the coefficient on CSR-Word is statistically insignificant. This finding is in line with the Locke et al. [18] case study, which documents technical cooperation between Nike and local suppliers in Central America and Asia. It also links to the literature that finds evidence for technology transfer between MNEs and their suppliers [43]. We, however, show that such technology transfer is stronger if the MNE is actively engaged in CSR-Deed.

Distinguishing the three types of knowledge transfer in columns 2 to 4 shows that MNEs that establish a dedicated department for local supplier development (CSR-Deed) are positively associated with all three types of knowledge transfer, although the coefficient estimate for "transfer of technology" in column 4 is by far the highest. By contrast, MNEs with a verbal CSR declaration only (CSR-Word) are not statistically significantly different from firms that make no such declaration. Thus, firms that demonstrate physical investments in local supplier development are more likely to support developing country suppliers through various forms of knowledge transfer as compared to firms from the CSR-Word group or indeed firms that are not engaged in CSR at all.

Overall, this shows that MNEs that have made physical investments in developing country suppliers as part of their CSR activities, CSR-Deed, are generally associated with higher levels of knowledge transfer from the affiliate to the local supplier. Such firms help to inject know-how relating to technology, financing, or workforce upgrading. By contrast, firms that claim to choose local suppliers based on CSR considerations (CSR-Word), but that lack such physical investments, are not associated with higher knowledge transfer. In this case, CSR words need to be accompanied by CSR deeds. 
Another important finding in the table is that MNEs that export to developed countries are also associated with higher technology transfer to suppliers. This also holds for all three types of technology transfer, with the strongest association being for "transfer of technology" in column 4 . When compared to CSR-Deed, the point estimates for exporting to the North are somewhat smaller, however. We also investigated a possible interaction of exporting to the North and the CSR variables but, similar to the wage regressions, these did not return any statistically significant results.

\section{Conclusions}

This paper examines whether multinational enterprises that claim to be engaged in CSR activities provide better working conditions and have stronger interactions with suppliers than MNEs making no such claims. Based on firm level data for 19 African countries, we can measure two aspects of CSR. The first CSR aspect is whether MNEs make the claim that supplier work conditions strongly influence their choice of supplier (CSR-Word). The second CSR aspect is whether MNEs demonstrably invest in local supplier development by establishing a dedicated local supplier department (CSR-Deed).

Our empirical analysis shows that MNEs with such a local supplier development department, on average, pay higher wages to their employees. This result lends support to the idea that these MNEs indeed behave more 'responsibly' to their workers than other firms. However, this result does not hold for the other definition of CSR activity.

When it comes to the relationship with local suppliers, there is also a stark difference between the two CSR modes. We find that MNEs that have demonstrably invested in a local supplier development department are more likely to provide knowledge transfer to their suppliers than other MNEs. However, applying the CSR-Word definition we find no such evidence of knowledge transfers.

Additionally, we find that export market orientation is significantly associated with the amount of assistance extended to suppliers by MNEs (knowledge transfer). This finding, concurs with the idea that MNEs, like the McDonalds food chain, discriminate by country groups when deciding on CSR practices. The destination of exports from Africa may have important implications for CSR. Future research, applying higher data granularity, should seek to deepen this finding and additionally consider the role of consumers in importing countries. A recent study [44] argues that even within a single importing country, consumers with differing levels of collective narcissism might have widely diverging perceptions of a company's CSR practices.

Our findings also have implications for consumers and policy makers. CSR labelling by multinational firms is an insufficient guarantee that the firm cares about suppliers in developing countries. Before a consumer is able to make an informed purchasing decision, additional information may be required on what the MNEs CSR activities actually entail. Our findings hint that CSR conscious consumers require higher transparency about how MNEs interact with local suppliers in catch-up economies. Only then, can consumers make authentic choices between international firms claiming to care about CSR.

Our analysis is based on firm level data for 2010. The advantage of this data is that it allows for us to investigate firms across many African countries. But, it comes with two caveats that are worth noting. Firstly, the data is slightly dated. While we do not have any indication that this severely hampers the generalizability of the findings, it is an issue that needs to be kept in mind. Secondly, the data only relate to one year and do not allow us to follow any dynamic development of CSR, wages, or technology transfer. Expanding the data to include information for more up-to-date years remains a goal for further research.

Overall, our results suggest that, for CSR to realize its full potential in improving supplier conditions, MNEs need to be prepared to make physical investments in local supplier development. Words must be accompanied by deeds. This has implications for further research on CSR. Researchers need to pay particular attention to the definition of CSR and check that written statements are accompanied by actual commitments, be they financial or otherwise. 
Author Contributions: Conceptualization, H.G. and A.S., Methodology, H.G. and A.H., data curation, A.H. and A.S.; writing—original draft preparation, H.G., A.H., A.S.; writing—review and editing, H.G., A.H.

Funding: Financial support from the Leibniz Association through the Leibniz Science Campus "Kiel Centre for Globalization" is gratefully acknowledged. Financial contribution from the European Union towards collection of data is also gratefully acknowledged.

Conflicts of Interest: The authors declare no conflict of interest. The funders had no role in the design of the study; in the collection, analyses, or interpretation of data; in the writing of the manuscript, or in the decision to publish the results.

\section{Appendix A}

Main Sub-Sector of the Company's Business Activity

Agriculture, hunting and related servic

Freq. Percent

Forestry, logging and related service a

$\begin{array}{ll}75 & 7.09\end{array}$

Fishing, operation of fish hatcheries a

20.19

Mining of coal and lignite; extraction

0.38

Extraction of crude petroleum and natur

0.76

Mining of metal ores

0.28

Other mining and quarrying

0.85

Manufacture of food products and bevera

1.23

Manufacture of tobacco products

15.12

Manufacture of textiles

0.95

Manufacture of wearing apparel; dressin

3.50

Tanning and dressing of leather; manufa

Manufacture of wood and of products of

Manufacture of paper and paper products

Publishing, printing and reproduction o

Manufacture of coke, refined petroleum

Manufacture of chemicals and chemical $p$

Manufacture of rubber and plastics prod

Manufacture of other non-metallic miner

Manufacture of basic metals

Manufacture of fabricated metal product

Manufacture of machinery and equipment

Manufacture of office, accounting and c

Manufacture of electrical machinery and

Manufacture of radio, television and co

Manufacture of medical, precision and o

Manufacture of motor vehicles, trailers

Manufacture of other transport equipment

Manufacture of furniture; manufacturing

Recycling

Other manufacturing

Electricity, gas, steam and hot water s

Collection, purification and distribution

Construction

Sale, maintenance and repair of motor $\mathrm{v}$

Wholesale trade and commission trade, $\mathrm{e}$

Retail trade, except of motor vehicles

Hotels and restaurants

Water transport

Other business activities 


\section{References}

1. Xing, Y.; Detert, N. How the iPhone Widens the United States Trade Deficit with the People's Republic of China. ADBI Working Paper Series No. 257. December 2010. Available online: http://hdl.handle.net/11540/ 3845 (accessed on 29 September 2017).

2. Wilshaw, R. Steps Towards a Living Wage in Global Supply Chains, Oxfam. Available online: https://www. oxfam.org/en/research/steps-towards-living-wage-global-supply-chains (accessed on 29 September 2017).

3. United Nations Conference on Trade and Development (UNCTAD). Corporate Social Responsibility in Global Value Chains; UNCTAD/DIAE/ED/2012/3; UNCTAD: Geneva, Switzerland, 2012. Available online: http:/ / unctad.org/en/PublicationsLibrary / diaeed2012d3_en.pdf (accessed on 29 September 2017).

4. Wagner, T.; Lutz, R.J.; Weitz, B.A. Corporate hypocrisy: Overcoming the threat of inconsistent corporate social responsibility perceptions. J. Mark. 2009, 73, 77-91. [CrossRef]

5. Murphy, P.E.; Schlegelmilch, B.B. Corporate social responsibility and corporate social irresponsibility: Introduction to a special topic section. J. Bus. Res. 2013, 66, 1807-1813. [CrossRef]

6. Bowen, F. After Greenwashing: Symbolic Corporate Environmentalism and Society; Cambridge University Press: Cambridge, UK, 29 March 2014; ISBN 13: 978-1107034822.

7. Delmas, M.A.; Burbano, V.C. The Drivers of Greenwashing. Calif. Manag. Rev. 2011, 54, 64-87. [CrossRef]

8. Aguinis, H.; Glavas, A. What we know and don't know about Corporate Social Responsibility: A Review and Research Agenda. J. Manag. 2012, 38, 932-968. [CrossRef]

9. Lund-Thomsen, P.; Lindgreen, A. Corporate social responsibility in global value chains: Where are we now and where are we going? J. Bus. Ethics 2014, 123, 11-22. [CrossRef]

10. Kitzmueller, M.; Shimshack, J. Economic perspectives on corporate social responsibility. J. Econ. Lit. 2012, 50, 51-84. [CrossRef]

11. Baron, D.P. Corporate social responsibility and social entrepreneurship. J. Econ. Manag. Strategy 2007, 16, 683-717. [CrossRef]

12. Siegel, D.S.; Vitaliano, D.F. An empirical analysis of the strategic use of corporate social responsibility. J. Econ. Manag. Strategy 2007, 16, 773-792. [CrossRef]

13. Price, J.M.; Sun, W. Doing good and doing bad: The impact of corporate social responsibility and irresponsibility on firm performance. J. Bus. Res. 2017, 80, 82-97. [CrossRef]

14. McWilliams, A.; Siegel, D. Corporate social responsibility and financial performance: Correlation nor misspecification? Strateg. Manag. J. 2000, 21, 603-609. [CrossRef]

15. McWilliams, A.; Siegel, D. Corporate social responsibility: A theory of the firm perspective. Acad. Manag. Rev. 2001, 26, 117-127. [CrossRef]

16. Matten, D.; Moon, J. "Implicit" and "explicit" CSR: A conceptual framework for understanding CSR in Europe. In CSR Across Europe; Habisch, A., Jonker, J., Wegner, M., Schmidpeter, R., Eds.; Springer: Berlin, Germany, 2004; pp. 335-356.

17. Crouch, C. Modelling the firm in its market and organizational environment: Methodologies for studying corporate social responsibility. Organ. Stud. 2006, 27, 1533-1551. [CrossRef]

18. Locke, R.M.; Amanguel, M.; Mangla, A. Virtue out of necessity: Compliance, commitment, and the improvement of labor standards. Politics Soc. 2009, 37, 319-351. [CrossRef]

19. Park, B., II; Chidlow, A.; Choi, J. Corporate social responsibility: Stakeholder influence on MNEs' activities. Int. Bus. Rev. 2014, 23, 966-980. [CrossRef]

20. Zheng, Q.; Luo, Y.; Maksimov, V. Achieving legitimacy through corporate social responsibility: The case of emerging economy firms. J. World Bus. 2015, 50, 389-403. [CrossRef]

21. Roberts, S. Supply chain specific? Understanding the patchy success of ethical sourcing initiatives. J. Bus. Ethics 2003, 44, 159-170. [CrossRef]

22. Andersen, M.; Skjoett-Larsen, T. Corporate social responsibility in global supply chains. Supply Chain Manag. 2009, 14, 75-86. [CrossRef]

23. Baron, D.P. Morally motivated self-regulation. Am. Econ. Rev. 2010, 100, 1299-1329. [CrossRef]

24. Boehe, D.M.; Cruz, L.B. Corporate social responsibility, product differentiation strategy and export performance. J. Bus. Ethics 2010, 91, 325-346. [CrossRef]

25. Görg, H.; Hanley, A.; Hoffmann, S.; Seric, A. When do Multinational Companies Consider Corporate Social Responsibility? A Multi-Country Study in Sub-Saharan Africa. Bus. Soc. Rev. 2017, 122, 191-220. [CrossRef] 
26. Jenkins, R. Corporate Codes of Conduct. Self-Regulation in a Global Economy; United Nations Research Institute for Social Development: Geneva, Switzerland, 1 April 2001; ISBN 1020-8216.

27. Carlos, W.C.; Lewis, B.W. Strategic silence: Withholding certification status as a hypocrisy avoidance tactic. Adm. Sci. Q. 2018, 63, 130-169. [CrossRef]

28. Pope, S.; Wæraas, A. CSR-washing is rare: A conceptual framework, literature review, and critique. J. Bus. Ethics 2016, 137, 173-193. [CrossRef]

29. Lock, I.; Seele, P. The credibility of CSR (corporate social responsibility) reports in Europe. Evidence from a quantitative content analysis in 11 countries. J. Clean. Prod. 2016, 122, 186-200. [CrossRef]

30. Greenwood, M.; Van Buren, H., III. Trust and stakeholder theory: Trustworthiness in the organisation-stakeholder relationship. J. Bus. Ethics 2010, 95, 425-438. [CrossRef]

31. Stender, S.; Dyerberg, J.; Astrup, A. High levels of industrially produced trans fat in popular fast foods. N. Engl. J. Med. 2006, 354, 1650-1652. [CrossRef] [PubMed]

32. Bansal, P.; Roth, K. Why companies go green: A model of ecological responsiveness. Acad. Manag. J. 2000, 43, 717-736.

33. Lyon, T.P.; Maxwell, J.W. Greenwash: Corporate environmental disclosure under threat of audit. J. Econ. Manag. Strategy 2011, 20, 3-41. [CrossRef]

34. Kim, E.H.; Lyon, T.P. Greenwash vs. brownwash: Exaggeration and undue modesty in corporate sustainability disclosure. Organ. Sci. 2015, 26, 633-940. [CrossRef]

35. Birkinshaw, J.; Bresman, H.; Nobel, R. Knowledge transfer in international acquisitions: A retrospective. J. Int. Bus. Stud. 2010, 41, 21-26. [CrossRef]

36. UNIDO (United Nations Industrial Development Organization). Africa Investor Report 2011; UNIDO: Vienna, Austria, 2011. Available online: https:/ / www.unido.org/sites /default/files/2013-02/AIS_Report_A4_0. PDF (accessed on 28 August 2018).

37. Waddock, S.A.; Graves, S.B. The Corporate Social Performance-Financial Performance Link. Strateg. Manag. J. 1997, 18, 303-319. [CrossRef]

38. Mishra, S.; Suar, D. Does Corporate Social Responsibility Influence Firm Performance of Indian Companies. J. Bus. Ethics 2010, 95, 571-601. [CrossRef]

39. Perez Villar, L.; Seric, A. Knowledge Transfer in Global Supply Chains: Multinationals in Sub-Saharan Africa. Kiel Working Paper 1994. 2015. Available online: https://www.ifw-kiel.de/datenmigration/publikationen/ document-store/knowledge-transfer-in-global-supply-chains-multinationals-in-sub-saharan-africa$7885 /$ (accessed on 12 September 2018).

40. Strobl, E.; Thornton, R. Do Large Employers Pay More? The Case of Five Developing African Countries. J. Econ. Dev. 2004, 29, 137-161.

41. Gold, R.; Görg, H.; Hanley, A. South-South FDI: Is it really different? Rev. World Econ. 2017, 153, $657-673$. [CrossRef]

42. Girma, S.; Görg, H. Evaluating the foreign ownership wage premium using a difference-in-differences matching approach. J. Int. Econ. 2007, 72, 97-112. [CrossRef]

43. Driffield, N.; Love, J.H.; Menghinello, S. The multinational enterprise as a source of international knowledge flows: Direct evidence from Italy. J. Int. Bus. Stud. 2010, 41, 350-359. [CrossRef]

44. Antonetti, P.; Maklan, S. Social identification and corporate irresponsibility: A model of stakeholder punitive intentions. Br. J. Manag. 2016, 27, 583-605. [CrossRef]

(C) 2018 by the authors. Licensee MDPI, Basel, Switzerland. This article is an open access article distributed under the terms and conditions of the Creative Commons Attribution (CC BY) license (http://creativecommons.org/licenses/by/4.0/). 